\title{
Antisipasi Didaktis dengan Strategi Scaffolding pada Pembelajaran Barisan dan Deret Aritmetika
}

\author{
Mariyani $^{1 *}$, Nyiayu Fahriza Fuadiah ${ }^{2}$, Allen Marga Retta ${ }^{3}$ \\ ${ }^{1,2,3}$ Program Studi Pendidikan Matematika, Universitas PGRI Palembang \\ *mariyanimathedu@gmail.com
}

\begin{abstract}
Abstrak
Penelitian ini bertujuan untuk menjelaskan antisipasi didaktis pada pembelajaran barisan dan deret aritmetika. Penelitian menggunakan didactical design research melalui tiga tahap yaitu analisis prospektif, analisis metapedadidaktik, dan analisis retrospektif. Data dikumpulkan melalui pengujian tes, wawancara, dan dokumentasi. Peneliti merancang HLT berdasarkan hasil analisis learning obstacle yang dialami siswa pada pembelajaran barisan dan deret aritmetika. Dari HLT tersebut kemudian dirancang desain didaktis. Desain didaktis diimplementasi dengan hasil yang menunjukkan bahwa terdapat tiga situasi didaktis yang peneliti antisipasi didaktis dengan strategi scaffolding yaitu : 1) pada saat menentukan nilai yang memenuhi pola bilangan, peneliti melakukan antisipasi didaktis dengan memberikan petunjuk berupa arahan untuk menyelesaikan soal yang diberikan; 2) pada saat menentukan definisi dan contoh dari barisan aritmetika, antisipasi didaktis yang dilakukan peneliti dengan memberikan contoh lain dari bentuk barisan bilangan membuat siswa lebih memahami pembelajaran yang diberikan; 3) pada saat menentukan nilai suku ke- $n$ dan jumlah $n$ suku pertama dari suatu barisan dan deret aritmetika, antisipasi didaktis yang diberikan yaitu dengan ke kemeja mereka masing-masing untuk mengecek pengerjaan mereka dan melakukan interaksi secara langsung. Antisipasi didaktis yang peneliti berikan pada penelitian ini disesuaikan dengan keadaan lingkungan di sekitar kelas.

Kata kunci: antisipasi didaktis, barisan dan deret aritmetika, scaffolding
\end{abstract}

\begin{abstract}
This study aims to explain didactic anticipation in learning arithmetic sequences and series. The study was conducted using a didactic design study with three stages: prospective analysis, metapedadidactic, and retrospective analysis. Data were collected through tests, interviews, and documentation. Researchers compile HLT based on the analysis of learning constraints for students in learning arithmetic sequences and series. From the HLT, a didactic design was designed. The didactic design is implemented with results showing that there are three didactic events that researchers anticipate didactic with a scaffolding strategy, namely: 1) when determining the value that satisfies the number pattern, the researcher anticipates the didactic by providing directions in the form of directions to solve the given problem; 2) when determining the definition and example of arithmetic sequences, the didactic anticipation by the researcher by providing another example of the form of a number sequence makes students better understand the learning given; 3) when determining the value of the nth term and the sum of the first $n$ terms of an arithmetic sequence and series, the didactic anticipation is given namely with their respective shirts to check their work and make direct interactions. The didactic anticipation that the researchers gave in this study was adjusted to the conditions of the environment around the classroom.
\end{abstract}

Keywords: didactic anticipation, arithmetic sequences and series, scaffolding

Received: April 8, 2021 / Accepted: June 2, 2021 / Published Online: July 14, 2021 


\section{Pendahuluan}

Matematika memiliki sifat tersendiri yang membedakannya dengan bidang ilmu lainnya. Matematika memiliki karakteristik pada penalaran logis dan aksiomatis yang disebut sebagai proses deduktif, yaitu proses penyusunan konjektur, menyusun model matematika yang sesuai, melakukan analogi dan atau generalisasi berdasarkan analisis terhadap data yang ada melalui proses induktif (Sumarmo, 2006). Mengingat sifat matematika tersebut, dibutuhkan kemampuan kognitif dan proses mental yang terjadi dalam pikiran seseorang dengan menghubungkan suatu konsep dengan konsep lainnya agar matematika dapat dipahami dan dipelajari dengan baik (Sutiarso, 2009).

Salah satu konsep yang harus dipelajari oleh siswa dalam matematika adalah barisan bilangan. Untuk dapat meminimalisir kesalahan matematis yang terjadi pada siswa, penting bagi guru untuk menganalisa penyebab kesalahan tersebut dari awal pembelajaran (Elbrink, 2007). Beberapa kesulitan siswa terkait dengan barisan dan deret adalah kesalahan keterampilan proses dan ketidaktahuan siswa dalam menentukan prosedur atau strategi yang tepat untuk menyelesaikan soal serta tidak dapat menyusun model matematika dari literasi soal yang diberikan (Septiahani, Melisari, \& Zanthy, 2020); rendahnya kemampuan siswa dalam memahami, merencanakan, dan menyelesaikan masalah (Pirmanto, Anwar, \& Bernard, 2020). Kesulitan lainnya yang muncul terkait dengan konsep dan mengaplikasi konsep dalam kehidupan sehari-hari (Fauzia, Juandi, \& Purniati, 2017; Sulistiawati, Arsyad, \& Minggi, 2019; Zebua, Rahmi, \& Yusri, 2020). Berdasarkan permasalahan tersebut, perlu adanya upaya untuk mengatasi kesulitan dan hambatan yang muncul khususnya pada materi barisan dan deret melalui perancangan atau desain pembelajaran yang tepat.

Dalam merancang suatu pembelajaran seorang pendidikan perlu untuk memprediksikan berbagai kemungkinan respon siswa atas situasi didaktis yang diberikan, hal ini dilakukan agar guru memiliki rencana tindakan atas setiap kemungkinan respon yang terjadi pada siswa yang disebut sebagai antisipasi didaktis (Suryadi, 2013). Oleh karena itu, guru harus memiliki kemampuan dalam merancang pembelajaran yang dapat mengantisipasi semua respon siswa yang mungkin terjadi pada situasi didaktis yang terjadi pada saat pembelajaran (Brousseau, 2002; Fuadiah, Suryadi, \& Turmudi, 2017). Aktivitas belajar mengajar dengan suasana yang inovatif juga dapat meningkatkan semangat dan minat siswa pada pembelajaran (Retta \& Nopriyanti, 2020). Menurut Brousseau (2002), teori situasi didaktis menekankan bahwa inovasi proses pengajaran dan pembelajaran yang dapat dimodelkan dalam suatu kegiatan yang mencakup tiga langkah utama. Pertama, situasi adidaktis diciptakan agar siswa dapat menggunakan pengetahuan yang telah ia dimiliki sebelumnya. Kedua, secara bersama- 
sama siswa berupaya menemukan cara-cara untuk meningkatkan pengetahuan mereka dalam mencapai tujuan pembelajaran. Ketiga, siswa diarahkan untuk mempertimbangkan kesimpulan pengetahuan yang mereka peroleh menjadi suatu konsep pengetahuan. Ketiga tahapan ini disebut situasi aksi, formulasi dan validasi. Berbagai tindakan didaktis dan umpan balik didukung dengan strategi yang tepat dalam tahapan tersebut diharapkan dapat mendorong terciptanya proses pengetahuan baru pada siswa

Brousseau (2002) menyatakan Theory of Didactical Situations in Mathematics (TDSM) sebagai konsep pengajaran modern menuntut guru untuk merangsang adaptasi dengan menyajikan "masalah" kepada siswa. Masalah ini harus dapat membuat siswa bertindak, berbicara, berpikir dan berkembang dengan motivasi mereka sendiri. Suryadi (2010) mengemukakan bahwa untuk menciptakan terjadinya aksi mental pada siswa, perlu adanya permasalahan yang memuat tantangan bagi siswa untuk berpikir yang diberikan pada awal pembelajaran. Masalah yang diberikan dapat berupa penemuan konsep, prosedur, strategi penyelesaian masalah atau aturan-aturan dalam matematika. Selanjutnya, Suryadi (2016) juga mengungkapkan jika aksi mental yang diharapkan tidak terjadi yaitu ditandai dengan ketidakmampuan siswa dalam menyelesaikan permasalahan yang diberikan, maka guru dapat melakukan intervensi atau bimbingan tidak langsung melalui penerapan teknik scaffolding berupa tindakan didaktis sebagai antisipasi didaktis yang dapat mendorong terjadinya interaksi antar siswa. Untuk mengembangkan pemikiran dan mengonstruksi pemikiran siswa secara individu serta mengarahkan pada pemahaman matematis yang valid, guru dapat mengupayakan suatu bimbingan (Ubaidah \& Aminudin, 2019).

Istilah scaffolding yang diperkenalkan oleh Wood, Bruner dan Ross pada tahun 1976 telah diinterpretasikan dan diterapkan dalam berbagai penelitian dan praktek pendidikan (Verenikina, 2008). Wells (1999) juga menyebutkan bahwa pemahaman scaffolding sebagai aplikasi langsung dan operasionalisasi konsep pengajaran pada zone of proximal development (ZPD) yang diperkenalkan oleh Vygotsky. Lebih lanjut, strategi scaffolding memfasilitasi kemampuan siswa untuk menguatkan pengetahuan sebelumnya dan mendalami informasi baru (Van Der Stuyf, 2002). Pada saat siswa mulai memahami pembelajaran, maka scaffolding yang diberikan semakin sedikit sehingga siswa mampu menyelesaikan atau menguasai konsep secara mandiri (Hartman, 1997). Hartman (1997) selanjutnya menjelaskan bahwa scaffolding pada pembelajaran dapat berupa model, isyarat, petunjuk, sebagian solusi, pemberian contoh yang relevan serta interaksi langsung antara guru dan siswa.

Beberapa hasil penelitian terkait penggunaan teknik scaffolding dalam pembelajaran matematika menunjukkan dampak yang positif terhadap kualitas pembelajaran, seperti adanya 
peningkatan kemampuan pemahaman matematika siswa SMP kelas VIII (Rachmawati \& Purnama, 2019). Pembelajaran melalui scaffolding yang dikombinasikan dengan teknik pembelajaran Probing-Prompting terbukti dapat mendorong siswa melakukan penemuan baru, melakukan interaksi secara sosial, melakukan refleksi, sehingga kemampuan siswa dalam memecahkan masalah meningkat secara signifikan yang berimbas pada hasil belajar siswa (Fatimah et.al, 2019; Sari \& Surya, 2017). Dalam penelitian-penelitian tersebut, teknik scaffolding dilakukan dengan memberikan siswa kebebasan untuk berfikir dan menyelesaikan masalah secara individu, akan tetapi siswa tetap diberikan bantuan ketika mengalami kesulitan. Anghileri (2006) menguraikan tahapan scaffolding dalam tiga level, yaitu: a) environmental provisions, tahap dimana guru menyediakan media yang sesuai agar siswa dapat belajar secara mandiri, pada tahap ini tidak terjadi interaksi antara guru dan siswa secara langsung; b) explaining, reviewing and restructuring, tahapan dengan proses menjelaskan, meninjau kembali, dan atau restrukturisasi melalui interaksi langsung antara guru dan siswa; dan c) developing conceptual thinking, melalui upaya meningkatkan pemahaman konsep melalui proses abstraksi, generalisasi, dan probabilitas. Sejalan dengan hasil penelitian di atas, interaksi yang terjadi dapat membantu siswa untuk belajar secara mandiri dan memecahkan suatu masalah dengan memberikan sejumlah petunjuk, dorongan, peringatan, menguraikan masalah ke dalam langkah-langkah pemecahan, serta dapat juga dengan tindakan guru memberikan contoh yang relevan (Baxter \& Williams, 2010).

Terkait materi barisan dan deret yang menjadi fokus dalam penelitian ini, berbagai upaya untuk mendorong pencapaian siswa pada materi barisan dan deret telah banyak dilakukan dan dikembangkan oleh beberapa peneliti. Diantaranya pada materi barisan dan deret aritmetika melalui pembelajaran skrip kooperatif yang telah terbukti dapat meningkatkan aktivitas dan hasil belajar siswa (Anwar, 2017). Implementasi model pembelajaran kooperatif tipe TAI (Teams Assisted Individualization) pada pembelajaran barisan dan deret dengan menekankan pada kerja sama dan kolabirasi antar siswa, baik secara mental, sikap, maupun sosial, terbukti dapat meningkatkan kemampuan kerja sama sekaligus pencapaian hasil belajar (Warsini, 2019). Beberapa penelitian lainnya mengembangkan pembelajaran pada materi barisan dan deret, baik pengembangan desain dan perangkat pembelajaran, media, maupun instrumen soal (Lewy, Zulkardi, \& Aisah, 2013; Palupi, Yuwono, \& Muksar, 2017; Purboningsih, 2015).

Penelitian-penelitian tersebut sebagian besar ini lebih menekankan pada pencapaian hasil akhir pada suatu kemampuan tertentu yang terlihat dari data yang dipaparkan secara kuantitatif. Namun demikian, tidak menutup kemungkinan ada tindakan didaktis guru dalam 
kegiatan pembelajaran namun tidak disampaikan secara utuh dan menyeluruh. Informasiinformasi bagaimana pembelajaran berlangsung, terutama bagaimana antisipasi didaktis diciptakan seorang pendidik sebagai tindakan didaktis terhadap respon siswa yang muncul dalam pembelajaran, perlu juga disampaikan dengan tujuan memberikan alternatif solusi bagi pendidik ketika menemui masalah yang sama melalui proses scaffolding. Dengan memberikan antisipasi didaktis berupa scaffolding yang tepat dapat membuat alur berpikir siswa dalam mempelajari materi barisan dan deret sesuai dengan lintasan belajar siswa. Dengan demikian tujuan pembelajaran dapat tercapai sesuai dengan yang diharapkan.

\section{Metode}

Penelitian ini menggunakan pendekatan kualitatif melalui Didactical Design Research (DDR) dalam tiga tahap penelitian, yaitu analisis prospektif sebelum pembelajaran, analisis metapedidaktik, dan analisis retrospektif. Pada tahap analisis prospektif peneliti melakukan analisis learning obstacle berdasarkan hasil tes learning obstacle, wawancara kepada guru dan analisis buku teks yang digunakan siswa yang kemudian disusun menjadi Hypothetical Learning Trajectory (HLT) pada materi barisan dan deret aritmetika dan dikembangkan ke dalam desain didaktis hipotetik. Kedua komponen ini terlebih dahulu divalidasi dari sisi konstruk dan konten oleh dua orang pakar pendidikan dan konten matematika. Tahap analisis metapedadidaktik dilakukan melalui uji coba desain. Pada tahap analisis retrospektif peneliti mengaitkan prediksi respon siswa dengan respon siswa dilengkapi dengan antisipasi didaktis pada saat implementasi desain didaktis hipotetik. Penelitian dilaksanakan di SMA Negeri 1 Kelapa. Subjek penelitiannya yaitu kelas XI IPA 1 terdiri dari 6 siswa yang menjadi subjek uji coba desain. Subjek dipilih secara acak oleh guru mata pelajaran yang bersangkutan.

Selain desain didaktis yang berisikan prediksi respon siswa dan antisipasi didaktisnya, Instrumen utama pada penelitian ini berupa soal tes learning obstacles, panduan wawancara, tes identifikasi akhir serta rekaman video pembelajaran. Teknik pengumpulan data yang pada penelitian ini yaitu dengan memadukan data dari hasil pengujian tes, wawancara, dan studi dokumentasi. Analisis data yang digunakan pada penelitian ini didasari oleh Model Miles dan Huberman yaitu data reduction, data display, dan conclusion drawing/verification (Sugiyono, 2016). Implementasi desain didaktis hipotetik pada sejumlah responden ditelaah melalui teori metapedadidaktik sekaligus sebagai proses validasi terhadap desain. 


\section{Hasil Penelitian}

Berdasarkan analisis learning obstacle terhadap hasil tes learning obstacle, wawancara kepada guru serta analisis buku teks yang digunakan siswa kemudian dari hasil analisis tersebut dirancang menjadi suatu HLT. Adapun secara garis besar draft HLT pada materi barisan dan deret aritmetika dapat dilihat pada Gambar 1 berikut.

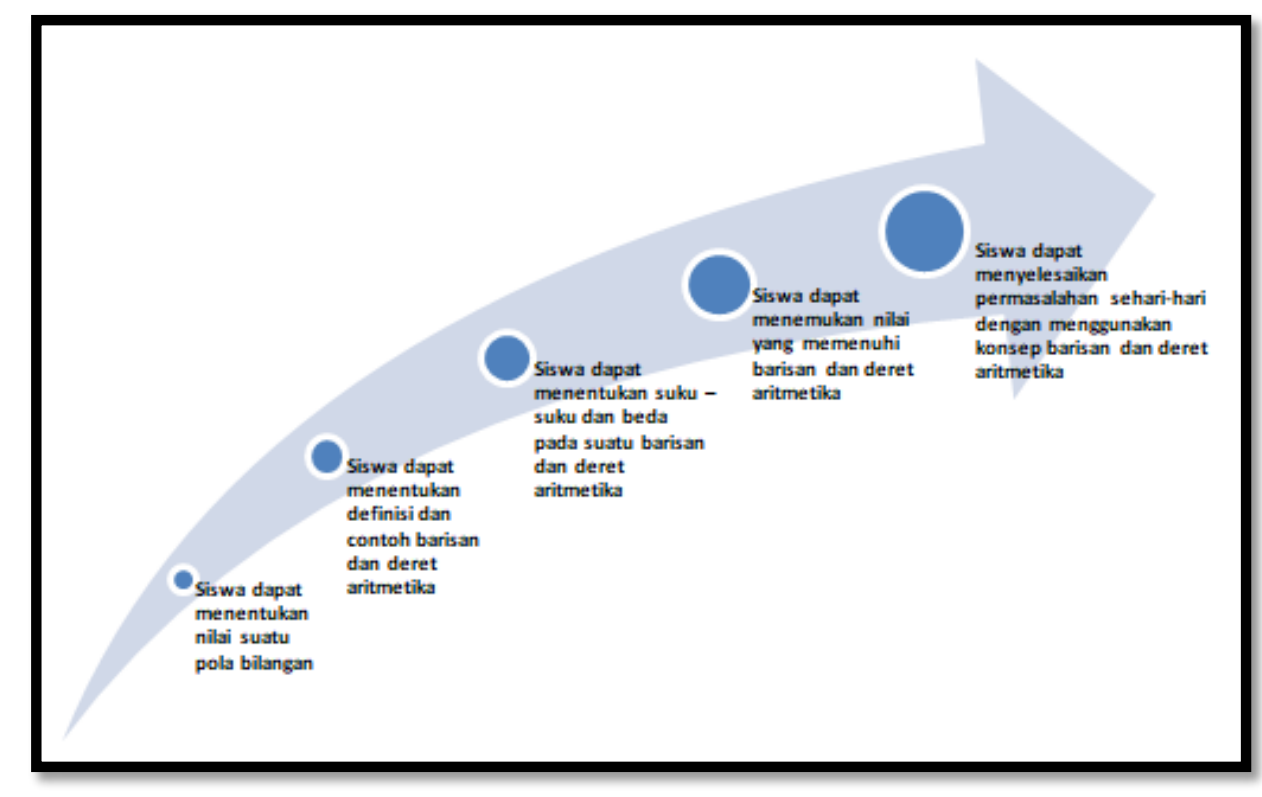

Gambar 1. HLT pada Materi Barisan dan Deret Aritmetika

HLT ini kemudian dikembangkan menjadi suatu desain pembelajaran yang memuat situasi didaktis serta prediksi berbagai respon siswa yang mungkin muncul pada saat kegiatan pembelajaran. Peneliti juga memberikan antisipasi terhadap respon siswa yang mungkin terjadi saat kegiatan pembelajaran sedang berlangsung. Berikut contoh beberapa kegiatan pembelajaran yang berisikan antisipasi didaktis berupa scaffolding.

\section{Menentukan Nilai dari Suatu Pola Bilangan}

Pada saat menentukan nilai yang memenuhi pola bilangan, kegiatan pembelajaran dimulai dengan peneliti memberikan soal mengenai pola bilangan dan siswa diminta untuk mengerjakan soal tersebut secara individu terlebih dahulu. Peneliti memberi waktu kepada siswa untuk mengerjakan soal tersebut. Berikut merupakan soal yang diberikan kepada siswa.

1. Perhatikan gambar berikut!

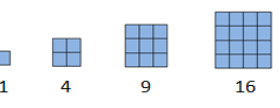

a. Pola apa yang terbentuk dari gambar diatas?

b. Tentukan rumus pola tersebut!

c. Tentukan pola ke-5 dan ke-6 dari gambar berikut! 
2. Diketahui rumus suku ke-n suatu pola bilangan adalah $U_{n}=10 n-3$. Tentukan nilai suku ke-21 adalah ...

Selanjutnya peneliti meminta siswa mengerjakan soal ke papan tulis. Namun tidak ada siswa yang maju ke depan, maka guru memberikan antisipasi didaktis dengan guru mengajak siswa untuk menjawab soal tersebut bersama-sama. Untuk lebih jelas aktivitas pembelajarannya dapat dilihat pada percakapan berikut.

$P \quad: \quad$ Untuk mengerjakan soal nomor 1. Ada yang mau maju ke depan?

SS : (Siswa diam)

$P \quad$ : Baiklah, kalo tidak ada. Coba perhatikan ke soalnya 1, 4, 9, 16 .... Pada pola pertama apakah yang terbentuk? Apakah pola persegi ?

$S S$ : Iya Bu, pola persegi.

$P \quad: \quad$ Pada pola kedua apakah masih membentuk persegi?

SS : Masih Bu.

$P \quad: \quad$ Pada pola selanjutnya apakah masih membentuk persegi?

SS : Masih.

$P \quad$ : Nah untuk soal yang a yaitu pola apakah yang terbentuk dari gambar diatas?

SS Pola persegi.

Berdasarkan percakapan di atas, terlihat bahwa siswa diam ketika diminta oleh guru untuk mengerjakan soal ke depan. Peneliti memberikan antisipasi didaktis dengan memberikan arahan untuk menyelesaikan soal tersebut. Oleh karena itu, antisipasi yang peneliti berikan merupakan salah satu dari bentuk strategi scaffolding yaitu berupa petunjuk penyelesaian. Dengan demikian antisipasi yang peneliti berikan mampu memberikan pemahaman dan membuat siswa memahami materi pembelajaran dengan baik. Hal ini diperkuat dengan penelitian Van Der Stuyf (2002) yang menjelaskan bahwa scaffolding dapat memberikan siswa kemampuan untuk mengingat kembali pengetahuan sebelumnya dan mendalami informasi baru.

Pada akhir pembelajaran kemudian peneliti megarahkan siswa untuk memvalidasi konsep pembelajaran yang telah dipelajari dengan memberikan stimulus berupa pertanyaanpertanyaan dalam diskusi kelas dan interaksi antara guru dan siswa secara aktif sehingga dicapai sebuah kesimpulan sesuai dengan tujuan pembelajaran.

$P \quad: \quad$ Setelah mengerjakan soal yang diberikan, apa yang kalian ketahui tentang pola bilangan?

S1 Bisa menentukan nilainya dengan rumus bu

$P \quad$ : Iya benar ya, jadi ketika kita telah mengetahui rumus yang berlaku untuk suatu pola

: bilangan, kita bisa menentukan suku-suku lain dengan menggunakan rumus tersebut.

: Sampai di sini ada yang ingin ditanyakan?

SS : Tidak Bu

$P \quad:$ Jadi semuanya paham?

SS : Paham bu

Dari percakapan diatas terlihat bahwa siswa memahami pembelajaran yang telah diberikan. Dengan demikian peneliti bisa melanjutkan penjelasan untuk materi selanjutnya. 


\section{Mengetahui Definisi Beserta Contoh Barisan dan Deret Aritmetika}

Pada saat menentukan definisi beserta contoh barisan dan deret aritmetika. Peneliti menggunakan media yang ada di sekitar ruangan kelas yaitu penggaris. Peneliti meminta siswa mengeluarkan penggaris yang mereka punya, kemudian peneliti meminta mereka untuk memperhatikan komponen-komponen yang terdapat pada penggaris tersebut. Selanjutnya peneliti meminta siswa untuk menyebutkan komponen apa saja yang terdapat pada penggaris tersebut. Aktivitas pembelajaran dapat dilihat pada percakapan berikut.

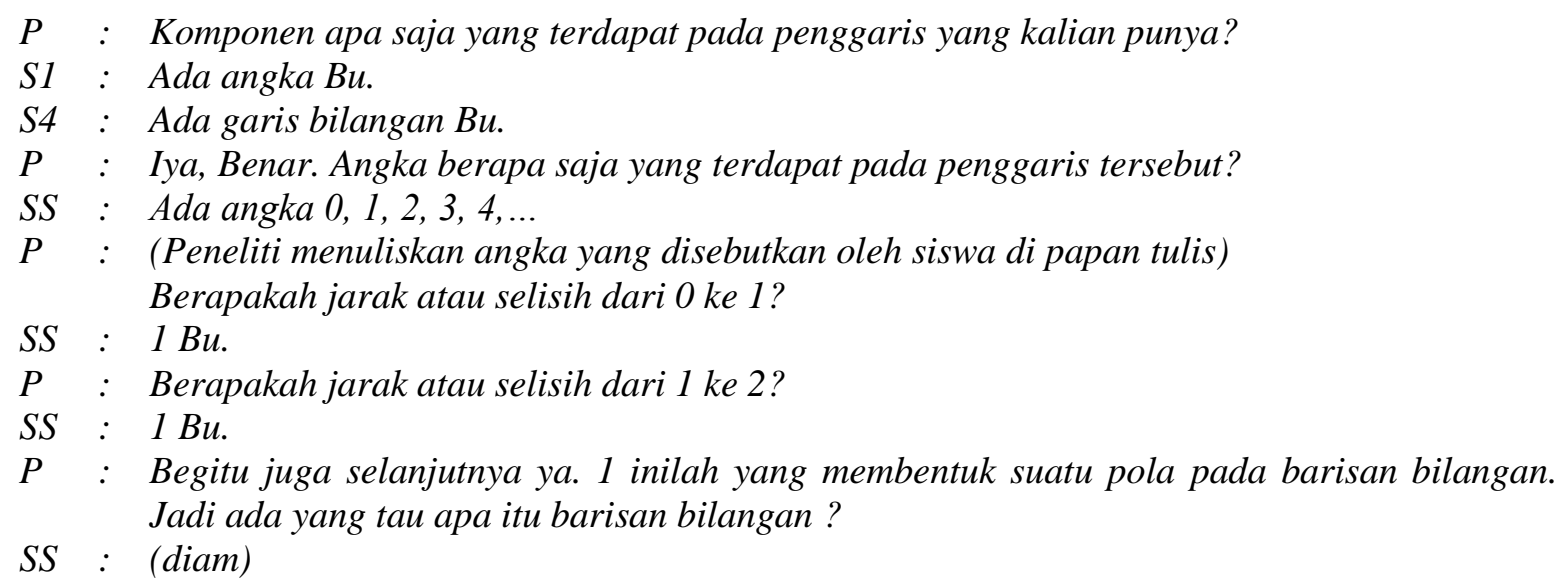

Dari percakapan di atas ternyata siswa belum memahami konsep barisan aritmetika yang peneliti jelaskan menggunakan alat bantu penggaris. Hal ini terlihat dari siswa yang diam ketika peneliti menanyakan kepada siswa apa itu barisan aritmetika. Oleh karena itu peneliti memberikan antisipasi didaktis berupa contoh lain yaitu masih dengan menggunakan alat yang ada di sekitar kelas tersebut yaitu jam dinding. Dari jam dinding tersebut peneliti meminta siswa untuk menyebutkan 4 angka inti yaitu 3, 6, 9, 12. Selanjutnya peneliti menjelaskan kaitan angka tersebut dengan barisan aritmetika dan membuat siswa lebih paham. Aktivitas pembelajaran yang berlangsung dapat dilihat pada percakapan berikut.

$P \quad$ : Coba perhatikan di sekitar kita, kira - kira apa contoh lain yang membentuk suatu pola?

SS : (Siswa mencari di sekeliling ruangan dan tidak menemukan contoh tersebut).

$P \quad$ : Contoh lain misalnya jam dinding, pada jam dinding ada 4 angka utama yaitu pada angka 3, selanjutnya angka berapa lagi ?

SS : Angka 6 Bu.

$P \quad: \quad$ (Peneliti menuliskan angka yang disebutkan oleh siswa) Selanjutnya angka berapa lagi?

SS : Angka 9 dan $12 \mathrm{Bu}$.

$P \quad$ : Iya jadi ada angka 3, 6, 9, 12. Coba perhatikan bilangan tersebut, jadi berapakah selisihnya? SS : $3 \mathrm{Bu}$.

$P \quad$ : Begitu juga seterusnya ya. Beda atau selisih yang tetap inilah yang mencirikan bahwa bilangan ini merupakan barisan aritmetika. Jadi barisan aritmetika merupakan barisan bilangan yang tersusun atas suku-suku yang memiliki selisih atau beda yang tetap.

SS : (Siswa menyimak penjelasan dari guru)

$P \quad$ : Dari definisi barisan aritmetika, coba berikan contoh lain dari barisan aritmetika? Coba S1 sebutkan contoh barisan aritmetika!

S1 : 5, 9, 13, 17...

$P \quad$ : Contoh yang disebutkan S1 apakah merupakan barisan aritmetika? 
SS : Iya Bu.

$P \quad: \quad$ Iya, benar sekali. Yang lain bagaimana, apakah sudah paham?

SS : Sudah Bu.

Berdasarkan percakapan diatas, antisipasi didaktis yang dilakukan peneliti dengan memberikan contoh lain dari bentuk barisan bilangan membuat siswa lebih memahami pembelajaran yang diberikan. Antisipasi didaktis yang diberikan juga merupakan salah satu bentuk scaffolding yaitu pemberian contoh lain yang relevan dengan pembelajaran. Contoh lain dari bentuk barisan aritmetika yang peneliti gunakan yaitu 4 angka utama pada jam dinding.

\section{Menentukan Suku-Suku Dan Beda Serta Rumus Umum Barisan Dan Deret Aritmetika}

Pembelajaran selanjutnya yaitu menentukan suku-suku dan beda serta rumus umum barisan dan deret aritmetika. Masih menggunakan konteks angka pada jam dinding. Peneliti meminta siswa untuk menentukan terlebih dahulu apa saja yang dapat mereka ketahui dari angka pada jam dinding tersebut. Setelah mereka menentukan apa saja yang diketahui dari angka pada jam dinding tersebut, barulah peneliti mengajak siswa untuk memeriksa kebenaran pengerjaan mereka. Adapun cuplikan kegiatan pembelajarannya dapat dilihat pada percakapan berikut.

$P \quad: \quad$ Coba perhatikan lagi bilangan 3, 6, 9, 12. Bilangan-bilangan tersebut merupakan suku-suku yang terdapat pada barisan aritmetika. Jadi angka 3 pada barisan tersebut merupakan suku ke berapa?

S4 : Suku ke-1 Bu

$P \quad$ : Iya benar ya. Angka 3 merupakan suku ke-1 atau suku pertama, suku ke-1 dilambangkan dengan $U_{1}$ atau a. Selanjutnya angka 6 merupakan suku ke berapa?

SS : Sukuke-2

$P \quad:$ Iya benar, suku ke-2 dilambangkan dengan apa?

$S S: U_{2} B u$

$P \quad$ : Jadi untuk mencari selisih atau bedanya yaitu $U_{2}-U \ldots$

$S S: U_{2}-U_{1} B u$

Berdasarkan percakapan tersebut terlihat bahwa siswa sudah mulai memahami tentang suku dan beda pada barisan dan deret aritmetika. Beberapa pertanyaan bantuan yang diberikan kepada siswa untuk memvalidasi konsep sehingga akhirnya mendapat kesimpulan bahwa $U_{1}=a, U_{2}=a+b, U_{3}=a+2 b, U_{n}=a+b$ dan rumus dari barisan aritmetika adalah $U_{n}=a+(n-1) b$.

Selanjutnya peneliti membagikan soal kepada berupa soal latihan yang dikerjakan secara individu dan dikumpul pada hari yang sama. Hasil pengerjaan soal ini peneliti jadikan acuan apakah mereka sudah memahami atau belum tentang materi yang disampaikan. Secara keseluruhan siswa sudah memahami materi yang disampaikan. Berikut merupakan contoh jawaban siswa dapat dilihat pada Gambar 2 di bawah ini. 


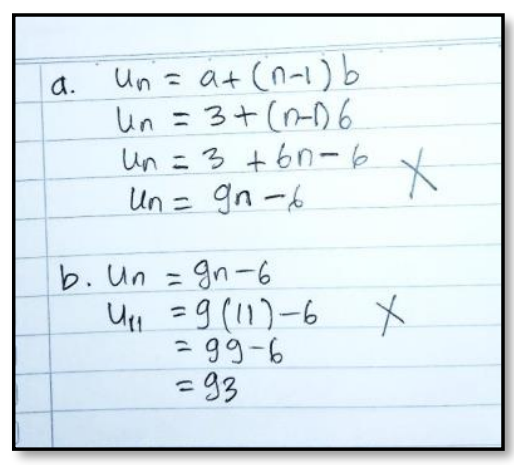

Gambar 2. Jawaban S3

Dari Gambar 2 tersebut terlihat masih terdapat kesalahan siswa dalam menentukan rumus yang berlaku untuk suatu barisan aritmetika. Kesalahan yang dilakukan oleh siswa tersebut yaitu pada penjumlahan bilangan yang memiliki variabel yaitu $3+6 n-6=9 n-6$ seharusnya yaitu $6 n-3$. Untuk mengatasi hal ini peneliti akan mengingatkan kembali materi yang belum dipahami siswa. Sehingga tidak akan terjadi lagi kesalahan yang sama pada pertemuan selanjutnya. Secara umum siswa terlihat sudah mampu mengerjakan soal latihan yang diberikan, namun masih ada siswa yang kurang teliti dalam mengerjakan soal yang diberikan. Gambar 3 berikut merupakan salah satu hasil pengerjaan siswa.
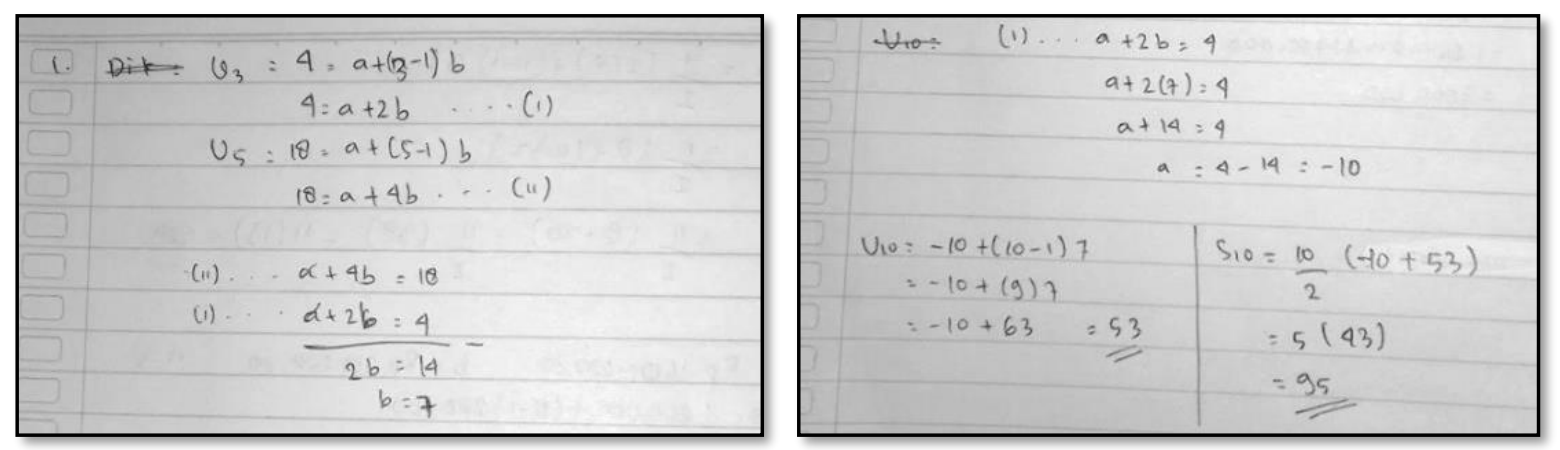

Gambar 3. Contoh Hasil Pengerjaan S4

Dari Gambar 3 diatas terlihat siswa kurang teliti dalam mengerjakan soal yang diberikan yaitu pada perkalian bilangan bulat. Kesalahan yang dialami siswa tersebut yaitu mengalikan bilangan $5(43)=95$, seharusnya hasil dari $5(43)=215$. Namun meski demikian secara prosedur siswa ini mampu mengerjakan soal yang diberikan hanya mengalami kesalahan pada saat mengalikan hasil akhirnya saja.

\section{Pembahasan}

Pada saat implementasi desain terdapat beberapa respon siswa yang tidak sesuai dengan respon yang telah peneliti prediksikan. Namun, seiring berjalannya proses pembelajaran peneliti berhasil memberikan antisipasi terhadap setiap respon yang diberikan oleh siswa. 
Antisipasi dengan scaffolding yang peneliti berikan didasari oleh pendapat Hartman (1997) dan Van Der Stuyf (2002). Van Der Stuyf (2002) menjelaskan bahwa scaffolding memberikan siswa kemampuan untuk mengingat kembali pengetahuan sebelumnya dan mendalami informasi baru. Sedangkan, Hartman (1997) menjelaskan bahwa scaffolding pada pembelajaran dapat berupa model, isyarat, petunjuk, sebagian solusi, pemberian contoh yang relevan dan interaksi langsung.

Pada tahap scaffolding pada pembelajaran matematika, guru dapat memberikan sejumlah pertanyaan ataupun pernyataan yang bertujuan untuk mendorong siswa merepresentasikan apa yang mereka lihat, mengulangi instruksi yang diberikan atau mengungkapkan kembali secara lisan apa yang telah mereka amati (Anghileri, 2006). Hal ini terlihat pada saat uji coba desain terlihat bahwa antisipasi yang diberikan oleh guru sebagian besar dilakukan melalui proses scaffolding terutama pada saat aksi formulasi dan validasi. Beberapa antisipasi dengan strategi scaffolding yang peneliti berikan yaitu 1) Pada saat menentukan nilai yang memenuhi pola bilangan, ketika siswa tidak bisa mengerjakan soal yang diberikan secara individu, peneliti melakukan antisipasi dengan memberikan petunjuk berupa arahan untuk menyelesaikan soal yang diberikan; 2) Pada saat menentukan definisi dan contoh dari barisan aritmetika, antisipasi yang dilakukan peneliti dengan memberikan contoh lain dari bentuk barisan bilangan membuat siswa lebih memahami pembelajaran yang diberikan; 3) Pada saat menentukan nilai suku ke- $n$ dan jumlah $n$ suku pertama dari suatu barisan dan deret aritmetika, antisipasi yang diberikan yaitu dengan ke kemeja mereka masing-masing untuk mengecek pengerjaan mereka dan melakukan interaksi secara langsung. Pemberian berbagai contoh yang relevan juga perlu dilakukan memperkuat pemahaman siswa. Pemberian contoh lain yang relevan merupakan salah satu bentuk scaffolding (Hartman, 1997)

Pemberian antisipasi yang peneliti lakukan juga didasari oleh pendapat Suryadi (2010) yang mengemukakan jika terdapat aksi mental yang diinginkan tidak terjadi yang terlihat dari ketidakmampuan siswa dalam memahami hubungan antar objek yang berkaitan dengan permasalahan yang terjadi, maka guru dapat melakukan intervensi secara tidak langsung dengan menerapkan teknik scaffolding (tindakan didaktis) serta menciptakan suatu aktivitas yang mendorong terjadinya interaksi antar siswa (tindakan pedagogis). Tindakan ini juga diperkuat oleh pendapat Brousseau (2002) yang mengemukakan bahwa tindakan didaktis yang dilakukan guru pada proses pembelajaran akan menciptakan suatu situasi untuk terjadinya proses belajar. 
Meskipun situasi didaktis yang dirancang tidak membuat terjadinya proses belajar, tetapi dengan adanya suatu pengkondisian misalnya melalui strategi scaffolding agar proses belajar akan sangat mungkin terjadi. Terjadinya proses belajar akan memunculkan situasi yang baru, bisa bersifat tunggal atau beragam tergantung dari milieu atau aktivitas belajar yang dirancang oleh guru (Suryadi, 2010). Semakin beragam milieu yang terjadi maka akan semakin beragam pula situasi yang terbentuk yang mengakibatkan proses pembelajaran menjadi lebih kompleks.

\section{Simpulan}

Terdapat tiga situasi didaktis yang peneliti antisipasi dengan strategi scaffolding. Pertama, pada saat menentukan nilai yang memenuhi pola bilangan, ketika siswa tidak bisa mengerjakan soal yang diberikan secara individu, peneliti melakukan antisipasi dengan memberikan petunjuk berupa arahan untuk menyelesaikan soal yang diberikan. Kedua, pada saat menentukan definisi dan contoh dari barisan aritmetika, antisipasi yang dilakukan peneliti dengan memberikan contoh lain dari bentuk barisan bilangan membuat siswa lebih memahami pembelajaran yang diberikan. Ketiga, pada saat menentukan nilai suku ke- $n$ dan jumlah $n$ suku pertama dari suatu barisan dan deret aritmetika, antisipasi didaktis yang diberikan yaitu dengan ke kemeja mereka masing-masing untuk mengecek pengerjaan mereka dan melakukan interaksi secara langsung. Antisipasi didaktis yang peneliti berikan pada penelitian ini disesuaikan dengan keadaan lingkungan di sekitar kelas. Hal ini dilakukan agar siswa lebih mudah untuk masuk kedalam situasi pembelajaran yang diberikan. Dengan mengantisipasi setiap respon yang siswa berikan proses pembelajaran di kelas dapat berjalan sebagaimana mestinya. Proses scaffolding sangat dibutuhkan baik dari guru sendiri maupun dari teman sebaya yang lebih memahami.

\section{Referensi}

Anghileri, J. (2006). Scaffolding practices that enhance mathematics learning. Journal of Mathematics Teacher Education, 9(1), 33-52. https://doi.org/10.1007/s10857-0069005-9.

Anwar, H. (2017). Hasil belajar barisan dan deret aritmatika melalui pembelajaran skrip kooperatif. Jurnal Penelitian Tindakan dan Pendidikan, 3(2), 113-122.

Brousseau, G. (2002). Theory of didactical situations in mathematics. New York: Kluwer Academic Publisher.

Baxter, J. A., \& Williams, S. (2010). Social and analytic scaffolding in middle school mathematics: Managing the dilemma of telling. Journal of Mathematics Teacher Education, 13(1), 7-26. https://doi.org/10.1007/s10857-009-9121-4.

Elbrink, M. K. (2007). Analyzing and addressing common mathematical errors in secondary 
education: an honors thesis (HONRS 499).

Fatimah, R. N., Kariadinata, R., Susilawati, W., Jihad, A., Fauziah, N. I., Solihatunnisa, L., Rosalia, N., Sa'adah, N., Sugilar, H. (2019). Teknik probing-promting scaffolding pada pemecahan masalah matematis. Prisma, 8(2), 146-159.

Fauzia, T. A. (2015). Desain didaktis konsep barisan dan deret aritmetika pada pembelajaran matematika sekolah menengah atas. Skripsi, Tidak dipublikasikan, Universitas Pendidikan Indonesia.

Fuadiah, N. F., Suryadi, D., \& Turmudi, T. (2017). Analysis of didactical contracts on teaching mathematics: A design experiment on a lesson of negative integers operations. Infinity Journal, 6(2), 157. https://doi.org/10.22460/infinity.v6i2.p157-168.

Hartman, H. (1997). Human learning and instruction. New York: City College of the City University of New York.

Lewy, L., Zulkardi, Z., \& Aisyah, N. (2013). Pengembangan soal untuk mengukur kemampuan berpikir tingkat tinggi pokok bahasan barisan dan deret bilangan di kelas IX akselerasi SMP Xaverius Maria Palembang. Jurnal Pendidikan Matematika, 5(1). https://doi.org/10.22342/jpm.5.1.821.

Palupi, E. W., Yuwono, I., \& Muksar, M. (2017). Pengembangan permainan kotak barisan yang digunakan pada kegiatan apersepsi materi barisan dan deret untuk meningkatkan motivasi siswa kelas X SMA. Jurnal Kajian Pembelajaran Matematika, 1(April), 10 16.

Pirmanto, Y., Anwar, M. F., \& Bernard, M. (2020). Analisis kesulitan siswa SMA dalam menyelesaikan soal pemecahan masalah pada materi barisan dan deret dengan langkahlangkah menurut Polya. Jurnal Pembelajaran Matematika Inovatif, 3(4), 371-384.

Purboningsih, D. (2015). Pengembangan perangkat pembelajaran dengan pendekatan guided discovery pada materi barisan dan deret untuk siswa SMK kelas X. Seminar Nasional Matematika dan Pendidikan Matematika UNY 2015, 467-474.

Rachmawati, I. \& Purnama, A. (2019). Penggunaan teknik scaffolding pada pembelajaran matematika untuk meningkatkan kemampuan pemahaman matematik pada siswa SMP. Jurnal Equation: Teori dan Penelitian Pendidikan Matematika, 2(2), 94. https://doi.org/10.29300/equation.v2i2.2314.

Retta, A. M., \& Nopriyanti, T. D. (2020). The reciprocal teaching model as the latest solution to improve students' mathematical representation ability. Journal of Physics: Conference Series, 1480(1), 012032. https://doi.org/10.1088/1742-6596/1480/1/012032.

Sari, N., \& Surya, E. (2017). Efektivitas penggunaan teknik scaffolding dalam meningkatkan hasil belajar matematika pada siswa SMP Swasta Al-Washliyah Medan. Edumatica: Jurnal Pendidikan Matematika, 7(1), 1-10.

Septiahani, A., Melisari, \& Zanthy, L. S. (2020). Analisis kesalahan siswa SMK dalam menyelesaikan soal materi barisan dan deret. Mosharafa Jurnal Pendidikan Matematika, 9(2), 311-322.

Sugiyono. (2016). Metode penelitian kuantitatif, kualitatif, dan R \& D. Bandung: Alfabeta.

Sulistiawati, I., Arsyad, N., \& Minggi, I. (2019). Deskripsi penalaran siswa dalam pemecahan masalah matematika pada pokok bahasan barisan dan deret ditinjau dari kemampan awal. Issues in Mathematics Education, 3(2), 111-118.

Sumarmo, U. (2006). Berpikir matematika tingkat tinggi: Apa, mengapa, dan bagaimana dikembangkan pada siswa sekolah menengah dan mahasiswa calon guru. Makalah pada Seminar Pendidikan Matematika di Jurusan Matematika FMIPA Universitas Padjajaran, Bandung: Tidak diterbitkan

Suryadi. D. (2010). Menciptakan proses belajar aktif: Kajian dari sudut pandang teori belajar dan teori didaktik. Bandung: Universitas Pendidikan Indonesia.

Suryadi, D. (2013). Didactical design research (DDR) dalam pengembangan pembelajaran 
matematika. Prosiding Seminar Nasional Matematika dan Pendidikan Matematika STKIP Siliwangi Bandung.

Suryadi, D. (2016). Didactical design research: Upaya membangun kemandirian berpikir melalui penelitian pembelajaran. In D. Suryadi et al. (Eds), Monograf Didactical Design Research. Bandung, Indonesia: Rizqi Press.

Sutiarso, S. (2009). Scaffolding dalam pembelajaran matematika. Dalam Pendidikan dan Penerapan MIPA (hal. 527-530). Yogyakarta: Universitas Negeri Yogyakarta.

Ubaidah, N., \& Aminudin, M. (2019). Development of learning tools: Learning constructivist mathematics to improve creative thinking ability. Journal of Physics: Conference Series, 1188(1), 012071. https://doi.org/10.1088/1742-6596/1188/1/012071.

Van Der Stuyf, R. R. (2002). Scaffolding as a teaching strategy. Adolescent learning and development, 52(3), 5-18.

Verenikina I. (2008) Scaffolding and learning: its role in nurturing new learners. In Learning and the Learner: Exploring Learning for New Times (eds Kell P., Vialle W., Konza D. and Vogl G.), pp. 161-180. University of Wollongong, Australia.

Warsini, T. (2020). Penerapan model TAI untuk meningkatkan kemampuan kerjasama dan hasil belajar matematika materi barisan dan deret kelas IXC SMP Negeri 4 Sumbang Semester 2 Tahun Pelajaran 2017/2018. AlphaMath: Journal of Mathematics Education, 5(2), 9-14. https://doi.org/10.30595/alphamath.v5i2.7334.

Wells, G. (1999). Dialogic Inquiry: Towards a socio-cultural practice and theory of education. Gordon Wells: University of Toronto. https://doi.org/10.1017/CBO9780511605895.

Zebua, V., Rahmi, R., \& Yusri, R. (2020). Analisis Kesalahan Siswa Dalam Menyelesaikan Soal Barisan dan Deret Ditinjau Dari Kemampuan Pemahaman Konsep Matematis. Jurnal LEMMA, 6(2), 122-133. https://doi.org/10.22202/j1.2020.v6i2.4088. 